\title{
Effect of Farmer Field School (FFS) on the Knowledge, Attitude, Practices and Profitability of Rice Farmers
}

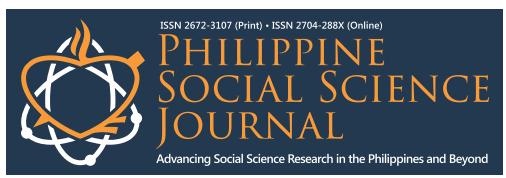

Froline S. Red ${ }^{1}$, Nilda T. Amestoso ${ }^{2}$ and Leomarich F. Casinillo ${ }^{3}$

$1,2,3$ Visayas State University, Visca, Baybay City, Leyte, Philippines

\section{Article history:}

Submitted: 9 September 2021

Revised: 22 November 2021

Accepted: 21 December 2021

\section{Keywords:}

KAP Model

Farmer field school

Rice farmers

Descriptive-comparative

Philippines
ABSTRACT. Knowledge, Attitude and Practice (KAP) Model explains the individual's knowledge which affects attitude and consequently changes the actual practices. The study investigated the effect of the Farmer Field School (FFS) on the knowledge, attitude, practices, and profitability of rice farmers in Babatngon, Leyte, Philippines. Ninety-four participants, which included 47 FFS farmers and 47 non-FFS farmers, were randomly chosen. Data were analyzed using descriptive and comparative statistics, cost and return analysis, and multiple regression analysis. Results showed that FFS farmers have a significantly higher level of knowledge than non-FFS farmers in the Palaycheck System ( $p$-value $<0.001$ ). Additionally, FFS farmers have a significantly great extent of practice than nonFSS farmers in the Palaycheck System ( $p$-value $<0.001$ ). Furthermore, farmers with high knowledge, positive attitude, and the great extent of practice on Palaycheck system gain more profit. Therefore, farmers should acquire more knowledge, a positive attitude, and more practice on production technologies to increase profit. Farmer Field Schools (FFS) and demonstration farms should be established in multi-locations to highlight the benefits of the Palaycheck technology for widespread adoption.

\subsection{Introduction}

Rice is the main food staple and most important commodity in the Philippines (Casinillo, 2020). According to Philippine Statistics Authority [PSA] (2018), rice production records for approximately $24 \%$ of gross value added (GVA) in the country's sector of agriculture. About two-thirds of the country's land that can be plowed are grown with rice, and it is a major source of income for many farmers (Yagos \& Demayo, 2015). It contributes 45\% of the population's total calorie intake on average and constitutes about $11 \%$ of the total household expenditure (PSA, 2018). However, climate change has negatively affected the country's food sector and smallholder farmers' agricultural livelihoods. This is coupled with increasing food prices and reducing investment support (Centino \& Vista, 2018). In that case, these worsen the poverty and food insecurity for the poor smallholder farmers. It is worthy to note that public policies that support growth and development among financially poor, ricevulnerable communities will be key to addressing these multiple challenges (Valenzona et al., 2020).

The Philippine Rice Research Institute (PhilRice) promoted Palaycheck System nationwide using the Farmer Field School (FFS) extension approach in support of the attainment of the rice self-sufficiency goal of the government (Mataia et al., 2015). Palaycheck System is a rice Integrated Crop Management System for irrigated lowland rice farming. It covers the principal areas of crop management such as seed quality, land preparation, crop establishment, nutrient management, pest management, water management, and harvest management (Castaňeda et al., 2009; Corales et al., 2014). The Department of Agriculture conducted FFS on Palaycheck System in Babatngon, Leyte, Philippines, to help increase rice farmers' knowledge and improve their skills and practices on rice production. The approach primarily focused on capacity building of the farmers through long-season training on Palaycheck System. Palaycheck System covered the major areas in the management of crops, mainly in the land preparation, seed qualification, establishment of crops, management of nutrients, management of pests, management of water supply, and management during harvesting. Palaycheck system promotes rice farmers to good management for their crops according to their goals, performance, and profitability. Moreover, Palaycheck can help farmers learn from their different experiences in improving their practices in crop management (Chi et al., 2004; Cruz et al., 2005).

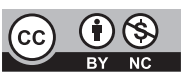

This article published by Philippine Social Science Journal (PSSJ) is licensed under a Creative Commons AttributionNoncommercial 4.0 International (CC BY-NC 4.0). You are free to share (copy and redistribute the material in any medium or format) and adapt (remix, transform, and build upon the material). Under the following terms, you must give appropriate credit, provide a link to the license, and indicate if changes were made. You may do so in any reasonable manner, but not in any way that suggests the licensor endorses you or your use. You may not use the material for commercial purposes. 
Furthermore, the FFS on Palaycheck System aimed to improve the yield and income of farmers in the municipality through access and availability of Palaycheck technology.

The implementation of government programs and the transfer of farm technology are also envisioned to improve the yield and profitability of farmers (Portera \& Hila, 2020; Manalo et al., 2021). In literature, limited studies have dealt with feedback mechanisms on the Palaycheck System to evaluate at the farm level how far the technology has achieved the goal of farmers in rural areas of Leyte, Philippines. Specifically, elucidating the effect of the Palaycheck System on the profitability of rice farmers in Babatngon, Leyte, has never been done. Thus, this study is realized. Hence, this study seeks to assess the effects of FFS on the Palaycheck System in rice farmers' knowledge, attitude, practices, and farm profitability to provide recommendations on improving the program implementation and formulating similar programs targeting smallholder farmers in other rural locations. Specifically, this study aimed to 1) describe the socio-demographic profile of the FFS farmers and non- FFS farmers in Babatngon, Leyte; 2) determine the rice farmers' level of knowledge, attitude, and practices on Palaycheck System with or without the program; 3 ) determine the rice farmers' farm profitability with or without the program; 4) examine the relationship between knowledge, attitude and practices on Palaycheck System to farm profitability of FFS farmers and non-FFS farmers; 5) examine the relationship between socio-demographic characteristics of the farmers with their knowledge, attitude, practices and profitability; and 6) recommend some innovative and relevant strategies to make the delivery of the FFS program more effective. Furthermore, the findings of the study may help the welfare of rice farmers and enhance current policy in rice production in rural areas.

\subsection{Framework of the Study}

This study conceptualized that the FFS training on Palaycheck System affects the farmers' knowledge, which is interpreted broadly to include the possession of analytical skills, critical thinking, ability to make better decisions, and familiarity with the Palaycheck System (Arellano \& Reyes, 2019; Samoy-Pascual et al., 2019). Farmers' attitude towards such knowledge affects their actual practice on Palaycheck System (Belanio et al., 2018). Hereafter, the knowledge, attitude, and practice of the Palaycheck System led to an increase in crop yield and farmers' profitability (Manalo et al., 2021). It is also expected that the rice farmers' socio-demographic characteristics may influence their knowledge, attitude, practices, and profitability (Casinillo, 2020). According to Price (2001), knowledge management practices of farmers gained from FFS will be geared toward a good farmers' management learning that will lead to better attitude and practices in farming behavior. Moreover, in the study of Cruz et al. (2005) and Mariano et al. (2012), it is mentioned that using modern technology and good management practices of the Palaycheck System can progress the productivity and profitability of the rice farmers.

\subsection{Methods}

Research design and locale. This study adopted the methodology of Casinillo (2020) and Valenzona et al. (2020) that deals with descriptive-correlational research design. Some descriptive statistics were used to summarize the gathered data. Some inferential statistics were employed to draw conclusions, predict and capture the relationships among variables. The study was conducted in Brgy. Bagong Silang and Governor E. Jaro, Babatngon, Leyte, Philippines. These were primarily agricultural barangays with an agricultural area of 772.42 hectares and 135 hectares, respectively. Farmers in these two barangays were the target beneficiaries of the Department of Agriculture's Farmer Field School (FFS) in the year 2017-2018.

Respondents and ethical procedure. The study first used stratified purposive sampling in choosing the respondents. First, two groups of respondents were considered - the rice farmers who were graduates of the FFS season-long training and those rice farmers who could not participate in the said training. Ninety rice farmers graduated from the FFS program. Among the graduates, 47 farmers were randomly selected as samples. On the other hand, 47 non-FFS farmers have been selected through judgment/selective sampling in the same localities. The researcher has implicitly chosen the samples based on their land area cultivated, type of rice field ecosystem, and non-involvement with the different extension services on rice farming systems, availability, and willingness to participate in the survey. 
Moreover, this study has considered an ethical procedure. Hence, before the conduct of the study, a letter of permission (consent) was sent to the head of the City Agriculture Office of Baybay City, Leyte. After the approval of the head, the researchers coordinated and asked the City Agriculture secretary for the list of rice farmers who graduated from FFS and farmers who had not attended the said training. After which, FFS and non-FFS farmers are oriented before gathering required information that their involvement in the survey will be voluntary, and anonymity is respected. Additionally, farmers' are informed that no sensitive information will be collected, and the gathered data will be confidential and used for research only. Furthermore, this study respects the respondents' privacy and conformed to the data privacy act, i.e., Republic Act. 10173.

Research instrument and data collection. A self-constructed survey questionnaire was used in this study to collect primary data from the respondents. The questionnaires were administered on a one-on-one interview to facilitate respondents' answers to the questions asked and ensure the accuracy of data collected. The questionnaire was categorized into five (5) parts. The first part collects data on the socio-demographic characteristics of the respondents. The second, third, and fourth parts were in the form of a Likert-type scale intended to gather information on the farmers' knowledge, attitude, and practices on the Palaycheck System. Table 1 shows the different Key Checks of crop management areas.

Table 1. Crop management areas and corresponding key checks

\begin{tabular}{lll}
\hline Crop Management Area & $\#$ & \multicolumn{1}{c}{ Key Check } \\
\hline Seed Quality & 1 & $\begin{array}{l}\text { Used of high-quality seeds of a } \\
\text { recommended variety }\end{array}$ \\
\hline Land Preparation & 2 & $\begin{array}{l}\text { No high and low soil spots after final } \\
\text { leveling }\end{array}$ \\
\hline Crop Establishment & 3 & $\begin{array}{l}\text { Practiced synchronous planting after a } \\
\text { fallow period }\end{array}$ \\
\hline Nutrient Management & 4 & Sufficient number of healthy seedlings \\
\hline Water Management & 5 & $\begin{array}{l}\text { Sufficient nutrients at tillering to early } \\
\text { panicle initiation, and flowering stages }\end{array}$ \\
\hline Pest Management & 6 & $\begin{array}{l}\text { Avoid excessive water or drought stress that } \\
\text { could affect the growth and yield of the } \\
\text { crop. }\end{array}$ \\
\hline Harvest Management & 8 & $\begin{array}{l}\text { No significant yield loss due to pests and } \\
\text { diseases }\end{array}$ \\
\hline
\end{tabular}

The knowledge of farmers was measured on a 5-scale Likert statement and obtained the following mean interval values and corresponding description: $1.00-1.80=$ very low, $1.81-2.60=$ low, 2.61-3.40=moderate, 3.41-4.20=high, 4.21-5.00=Very High. Farmers' attitude towards the Palaycheck System was measured on 6 -scale statements and attained the following mean interval values and corresponding description: $1.00-1.83=$ strongly disagree, $1.84-2.67=$ disagree, $2.68-3.50=$ somewhat disagree, $3.51-4.33=$ somewhat agree, $4.34-5.16=$ agree, $5.17-6.00=$ strongly agree. On the other hand, farmers' practices on Palaycheck System were measured on 5-scale statements. They obtained the following mean interval values and corresponding description: $1.00-1.80=$ small extent, $1.81-$ $2.60=$ some extent, $2.61-3.40=$ moderate extent, $3.41-4.20=$ great extent, $4.21-5.00=$ very great extent. Lastly, the fifth section collected information on rice yield, selling price, production cost, and fixed cost for the wet and dry seasons of 2019 for both the FFS and non-FFS farmers.

Data Analysis. Data were analyzed using descriptive statistics, including frequencies, percentages, and means. Mann Whitney $U$ test was used to determine the difference in the level of knowledge, attitude, practice, and profitability of the farmers. Cost and return analysis were prepared to determine the farm profitability of the FFS and non-FFS farmers. A multiple regression model 
was also fitted to determine the relationship between socio-demographic characteristics and FFS to knowledge, attitude practices, and profitability.

\subsection{Results and Discussion}

\section{Socio-demographic characteristics}

The FFS farmers are mostly (72.3\%) females, while non-FFS farmers are dominated $(76.6 \%)$ by males (Table 2). Regarding age, $72 \%$ of both FFS and non-FFS farmers are 30-59 years old. Most of the FFS and non-FFS farmers are married, almost $48 \%$ of whom are elementary graduates. About $43 \%$ are high school graduates, while almost $8 \%$ reached college. More than half $(57 \%)$ of the FFS farmers

\begin{tabular}{|c|c|c|c|c|c|c|c|}
\hline \multirow{2}{*}{\multicolumn{2}{|c|}{$\begin{array}{l}\text { Socio-Demographic } \\
\text { Characteristics }\end{array}$}} & \multicolumn{2}{|c|}{ FFS FARMER } & \multicolumn{2}{|c|}{ NON-FFS FARMER } & \multicolumn{2}{|c|}{ TOTAL } \\
\hline & & $\mathrm{N}$ & $\%$ & $\mathrm{~N}$ & $\%$ & $\mathrm{~N}$ & $\%$ \\
\hline \multirow[t]{3}{*}{ Gender } & Male & 13 & 27.7 & 36 & 76.6 & 49 & 52.1 \\
\hline & Female & 34 & 72.3 & 11 & 23.4 & 45 & 47.9 \\
\hline & Total & 47 & 100.0 & 47 & 100.0 & 94 & 100.0 \\
\hline \multirow[t]{5}{*}{ Age } & & \multicolumn{2}{|c|}{ Mean $=51 ; S D=10.9$} & \multicolumn{2}{|c|}{ Mean $=45 ; S D=12.2$} & \multicolumn{2}{|c|}{ Mean $=48 ; S D=11.9$} \\
\hline & 29 and below & 1 & 2.1 & 8 & 17.0 & 9 & 9.6 \\
\hline & $30-59$ & 34 & 72.3 & 34 & 72.3 & 68 & 72.3 \\
\hline & 60 and above & 12 & 25.5 & 5 & 10.6 & 17 & 18.1 \\
\hline & Total & 47 & 100.0 & 47 & 100.0 & 94 & 100.0 \\
\hline \multirow[t]{5}{*}{ Civil Status } & Single & 7 & 14.9 & 14 & 29.8 & 21 & 22.3 \\
\hline & Married & 38 & 80.9 & 30 & 63.8 & 68 & 72.3 \\
\hline & Widowed & 2 & 4.3 & 1 & 2.1 & 3 & 3.2 \\
\hline & Others & 0 & 0.0 & 2 & 4.3 & 2 & 2.1 \\
\hline & Total & 47 & 100.0 & 47 & 100.0 & 94 & 100.0 \\
\hline \multirow[t]{5}{*}{ Education } & Elementary & 20 & 43.5 & 23 & 52.3 & 43 & 47.8 \\
\hline & High School & 23 & 50.0 & 16 & 36.4 & 39 & 43.3 \\
\hline & College & 2 & 4.3 & 5 & 11.4 & 7 & 7.8 \\
\hline & Vocational & 1 & 2.2 & 0 & 0.0 & 1 & 1.1 \\
\hline & Total & 46 & 100.0 & 44 & 100.0 & 90 & 100.0 \\
\hline \multirow[t]{4}{*}{ Tenurial } & Owner & 17 & 36.2 & 29 & 64.4 & 46 & 50.0 \\
\hline & Tenant & 27 & 57.4 & 15 & 33.3 & 42 & 45.7 \\
\hline & Rental & 3 & 6.4 & 1 & 2.2 & 4 & 4.3 \\
\hline & Total & 47 & 100.0 & 45 & 100.0 & 92 & 100.0 \\
\hline \multicolumn{2}{|c|}{ Years in farming } & \multicolumn{2}{|c|}{ Mean $=24.4 ; S D=12.2$} & \multicolumn{2}{|c|}{ Mean $=16.8 ; S D=10.5$} & \multicolumn{2}{|c|}{ Mean $=20.7 ; S D=12.0$} \\
\hline & 15 and less & 15 & 31.9 & 22 & 50.0 & 37 & 40.7 \\
\hline & 16 and 30 & 18 & 38.3 & 18 & 40.9 & 36 & 39.6 \\
\hline & 31 and above & 14 & 29.8 & 4 & 9.1 & 18 & 19.8 \\
\hline & Total & 47 & 100.0 & 44 & 100.0 & 91 & 100.0 \\
\hline \multicolumn{2}{|l|}{ Area } & \multicolumn{2}{|c|}{ Mean $=1.078 ; \mathrm{SD}=0.06$} & \multicolumn{2}{|c|}{ Mean $=1.063 ; S D=0.02$} & \multicolumn{2}{|c|}{ Mean $=1.070 ; S D=0.03$} \\
\hline
\end{tabular}

are tenants (60\%) who have been farming for an average of 16 to 30 years, while non-FFS farmers are landowners. $50 \%$ of them have been farming for 15 years at the most. All of them are cultivating an average of around 1 hectare.

Table 3. Annual sources of household income of FFS farmers and non-FFS farmers

\begin{tabular}{lllllll}
\hline \multirow{2}{*}{ Income Sources } & \multicolumn{2}{c}{ FFS Farmer } & \multicolumn{2}{c}{ Non-FFS Farmer } & \multicolumn{2}{c}{ Total } \\
\cline { 2 - 7 } & $\mathrm{N}$ & $\%$ & $\mathrm{~N}$ & $\%$ & $\mathrm{~N}$ & $\%$ \\
\hline 10,000 and below & 0 & 0.0 & 2 & 4.3 & 2 & 2.1 \\
10,001 to 20,000 & 5 & 10.6 & 11 & 23.4 & 16 & 17.0 \\
20,001 to 30,000 & 15 & 31.9 & 16 & 34.0 & 31 & 33.0 \\
30,001 to 40,000 & 15 & 31.9 & 10 & 21.3 & 25 & 26.6 \\
40,001 to 50,000 & 12 & 25.5 & 8 & 17.0 & 20 & 21.3 \\
Total & 47 & 100.0 & 47 & 100.0 & 94 & 100.0 \\
\hline \multirow{2}{*}{ Rice } & Mean=32,882.73 & Mean=27,028.69 & Mean=29,955.71 \\
& $\mathrm{SD}=11,089.53$ & $\mathrm{SD}=9,789.20$ & $\mathrm{SD}=10,273.81$ \\
\hline \multirow{2}{*}{ Livestock } & $\mathrm{Mean}=14,528$ & $\mathrm{Mean}=25,367$ & Mean $=18,593$ \\
& $\mathrm{SD}=11,521.1$ & $\mathrm{SD}=14,672.2$ & $\mathrm{SD}=16,441.3$ \\
\hline \multirow{2}{*}{ Poultry } & $\mathrm{Mean}=24,100$ & $\mathrm{Mean}=11,618$ & $\mathrm{Mean}=19,015$ \\
& $\mathrm{SD}=13,823.1$ & $\mathrm{SD}=10,701.2$ & $\mathrm{SD}=28,811.9$ \\
\hline \multirow{2}{*}{ Vegetable } & $\mathrm{Mean}=19,565$ & $\mathrm{Mean}=14,600$ & $\mathrm{Mean}=18,186$ \\
& $\mathrm{SD}=14,567.2$ & $\mathrm{SD}=12,891.5$ & $\mathrm{SD}=17,231.6$ \\
\hline \multirow{2}{*}{ Non-farm } & $\mathrm{Mean}=44,982$ & $\mathrm{Mean}=37,298$ & $\mathrm{Mean}=40,902$ \\
& $\mathrm{SD}=38,788.9$ & $\mathrm{SD}=33,789.3$ & $\mathrm{SD}=39,675.6$ \\
\hline
\end{tabular}


Most FFS and non-FFS farmers rely on rice farming as the primary source of income (Table 3). The highest annual income of farmer respondents was Php 50,000, with a bigger proportion from FFS farmers (25.5\%) than the non-FFS farmers (17\%). The average annual rice income of all respondents was Php 29,955.71. It was observed that the average annual rice income of the FFS farmers was higher by Php 5,854.04 than of the non-FFS farmers. This may indicate that high-income farmers are more likely to employ new production technologies than farmers with lower incomes. This result parallels the findings of Mataia et al. (2015) that the FFS PalayCheck system leads to an improvement in management practices and technology adoption in farming.

\section{Knowledge, Attitude, and Practices on Palaycheck System}

Table 4 shows that FFS farmers have a higher level of knowledge (4.03) than non-FSS farmers' level of knowledge (3.47). Statistically, FFS and non-FFS farmers have a highly significant (at $1 \%$ level) difference of 0.56 in terms of their level of knowledge on the Palaycheck system $(U=467$, $\mathrm{p}$-value $<0.000$ ). This indicates that those farmers under the FFS program have better knowledge of the Palaycheck system compared to the non-FFS farmers. FFS farmers were taught how to manage the nutrient requirement of the rice crop based on nutrient assessment and decision support tools such as the Leaf Color Chart (LCC), Minus-One Element Technique (MOET), and soil analysis. The LCC is a kind of tool that can visualize the nitrogen condition of rice plants for assessment.

In contrast, MOET is an experiment that determines the nutrient status of the soil. It is worthy to note that knowledge of the right amount of fertilizer is very important for productive crops. Moreover, knowledge on the right judgment of a fertilizer application will somehow increase the

Table 4. Difference in the level of knowledge on Palaycheck System among FFS farmers and Non-FFS farmers

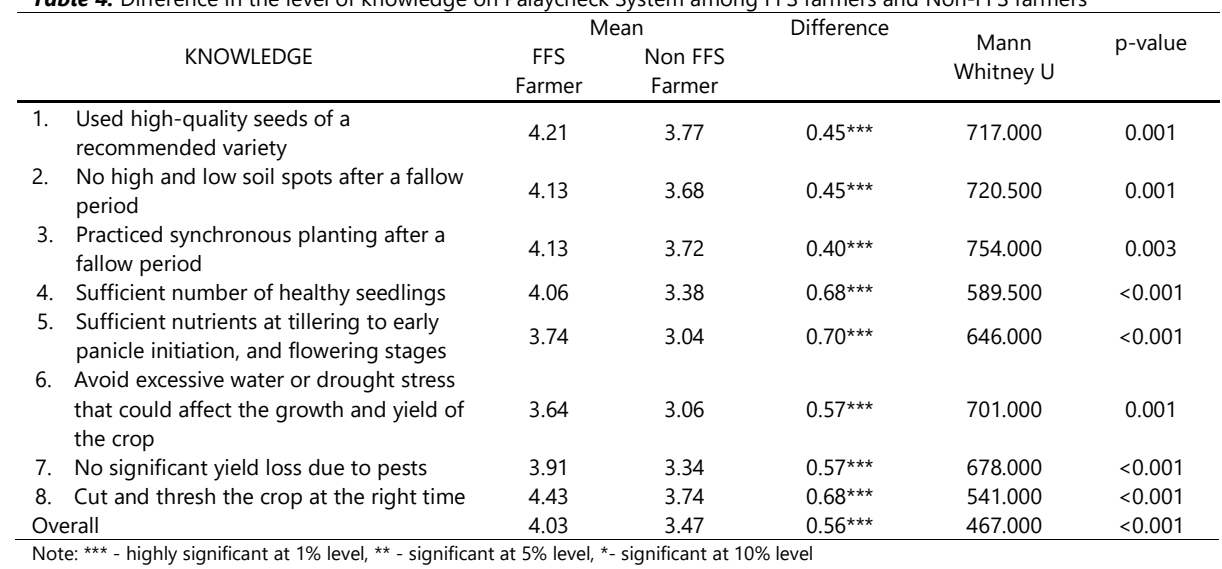

efficiency in the input cost and nutrient activity. These technologies under the Palaycheck System improve the farmers' understanding of rice crop production and their management skills (Corales et al., 2014; Mataia et al., 2015).

\section{Rice farmers' Attitude towards Palaycheck System}

In all key checks, the level of attitude towards the Palaycheck System of FFS farmers is higher in terms of mean (Table 5). FFS farmers agree (5.01) while non-FFS farmers somewhat agree (3.86) on Palaycheck System. FFS farmers and non-FFS farmers have a highly significant (at $1 \%$ level) difference of 1.15 in terms of their level of attitude towards the Palaycheck system $(U=375.5, p$-value $<0.000)$. Nevertheless, both groups have a positive attitude towards the Palaycheck System. Both FFS and non-FFS farmers have a positive attitude towards proper insect pests and diseases management. To avoid diseases, the field must be diagnosed correctly and practice field sanitation (Chi et al., 2004; Mataia et al., 2015). In addition, sufficient and efficient nutrient applications are what plants need to grow and become productive. Furthermore, gaining knowledge from FFS results in better pest management attitudes and practices to prevent harmful effects to neighboring humans (Mataia et al., 2015). 
Table 5. Difference in Attitude towards Palaycheck System of FFS farmers and non-FFS farmers

\begin{tabular}{|c|c|c|c|c|c|}
\hline \multirow[b]{2}{*}{ ATTITUDE } & \multicolumn{3}{|c|}{ Mean } & \multirow{2}{*}{$\begin{array}{c}\text { Mann Whitney } \\
\text { U }\end{array}$} & \multirow[b]{2}{*}{$\mathrm{p}$-value } \\
\hline & $\begin{array}{c}\text { FFS } \\
\text { Farmer }\end{array}$ & Non FFS Farmer & Difference & & \\
\hline $\begin{array}{l}\text { 1. Used high-quality seeds of a } \\
\text { recommended variety }\end{array}$ & 5.53 & 4.21 & $1.32^{* * *}$ & 278.000 & $<0.001$ \\
\hline $\begin{array}{l}\text { 2. No high and low soil spots after a fallow } \\
\text { period }\end{array}$ & 5.34 & 4.06 & $1.28^{* \star \star}$ & 333.500 & $<0.001$ \\
\hline $\begin{array}{l}\text { 3. Practiced synchronous planting after a } \\
\text { fallow period }\end{array}$ & 5.13 & 4.00 & $1.13^{* * *}$ & 473.000 & $<0.001$ \\
\hline 4. Sufficient number of healthy seedlings & 4.66 & 3.62 & $1.04^{* \star *}$ & 572.000 & $<0.001$ \\
\hline $\begin{array}{l}\text { 5. Sufficient nutrients at tillering to } \\
\text { flowering }\end{array}$ & 4.60 & 3.81 & $0.79^{* \star \star}$ & 682.500 & $<0.001$ \\
\hline $\begin{array}{l}\text { 6. Avoid excessive water or drought stress } \\
\text { that could affect the growth and yield of } \\
\text { the crop }\end{array}$ & 4.83 & 3.55 & $1.28^{* * *}$ & 459.500 & $<0.001$ \\
\hline 7. No significant yield loss due to pests & 4.83 & 3.74 & $1.09^{\star * *}$ & 553.500 & $<0.001$ \\
\hline 8. Cut and thresh the crop at the right time & 5.19 & 3.87 & $1.32^{\star \star \star}$ & 433.500 & $<0.001$ \\
\hline Overall & 5.01 & 3.86 & $1.15^{\star \star *}$ & 375.500 & $<0.001$ \\
\hline
\end{tabular}

\section{Rice Farmers' Practices on Palaycheck System}

FFS Farmers' level of practice on the Palaycheck System is higher than a non-FFS farmer in terms of mean (Table 6). FFS farmers practiced all key checks to a great extent (4.05). In contrast, non-FFS farmers practiced at a moderate extent (3.27) on Palaycheck System. FFS farmers have a statistically significant (at $1 \%$ level) great extent of practice by 0.77 than non-FSS farmers $(U=416, p$-value $<0.000)$. This implies that FFS farmers often prefer plating certified seeds and new rice varieties, believing that they yield better than non-FFS farmers (Philippine Rice Research Institute [PhilRice], 2007).

Table 6. Difference in Practice on Palaycheck System of FFS farmers and Non-FFS farmers

\begin{tabular}{|c|c|c|c|c|c|}
\hline \multirow{3}{*}{ PRACTICES } & \multicolumn{2}{|c|}{ Mean } & \multirow{3}{*}{ Difference } & \multirow{3}{*}{ Mann Whitney U } & \multirow{3}{*}{$\mathrm{p}$-value } \\
\hline & & Non FFS & & & \\
\hline & FFS Farmer & Farmer & & & \\
\hline $\begin{array}{l}\text { 1. Used high-quality seeds of a } \\
\text { recommended variety }\end{array}$ & 4.51 & 3.36 & $1.15^{\star \star \star}$ & 338.000 & $<0.001$ \\
\hline $\begin{array}{l}\text { 2. No high and low soil spots after a } \\
\text { fallow period }\end{array}$ & 4.38 & 3.38 & $1.00^{* \star *}$ & 415.000 & $<0.001$ \\
\hline $\begin{array}{l}\text { 3. Practiced synchronous planting after } \\
\text { a fallow period }\end{array}$ & 4.19 & 3.47 & $0.72^{\star \star *}$ & 593.000 & $<0.001$ \\
\hline $\begin{array}{l}\text { 4. Sufficient number of healthy } \\
\text { seedlings }\end{array}$ & 3.74 & 3.13 & $0.62^{\star \star *}$ & 692.500 & 0.001 \\
\hline $\begin{array}{l}\text { 5. Sufficient nutrients at tillering to } \\
\text { flowering }\end{array}$ & 3.60 & 3.06 & $0.53^{\star * *}$ & 759.000 & 0.006 \\
\hline $\begin{array}{l}\text { 6. Avoid excessive water or drought } \\
\text { stress that could affect the growth } \\
\text { and yield of the crop }\end{array}$ & 3.68 & 3.06 & $0.62^{\star \star \star}$ & 744.000 & 0.004 \\
\hline 7. No significant yield loss due to pests & 3.85 & 3.11 & $0.74^{\star \star *}$ & 616.500 & $<0.001$ \\
\hline $\begin{array}{l}\text { 8. Cut and thresh the crop at the right } \\
\text { time }\end{array}$ & 4.40 & 3.60 & $0.81^{\star \star \star}$ & 504.500 & $<0.001$ \\
\hline Overall & 4.05 & 3.27 & $0.77^{\star \star \star}$ & 416.000 & $<0.001$ \\
\hline
\end{tabular}

\section{Farmers' Rice Profitability for Wet Cropping Season Rice Production}

In the wet cropping season of 2019, FFS farmers produced a higher yield of $4,085.11 \mathrm{~kg}$ or $4.085 \mathrm{t} / \mathrm{ha}$ compared to non-FFS farmers with $3,400.00 \mathrm{~kg}$ or $3.4 \mathrm{t} / \mathrm{ha}$ (Table 7). A difference of 685.11 $\mathrm{kg}$ was highly significant at a $1 \%$ level $(\mathrm{U}=620.000$, $\mathrm{p}$-value $<0.001)$. This means that farmers under the FFS program had higher yields compared to the non-FFS. The practice of the key checks such as increased use of high-quality seeds of recommended variety, sufficient amount of fertilizer based on recommendations, and proper pest control strategies have contributed to the yield increase of FFS farmers. FFS farmers have a higher gross income of Php65,465.96 compared to non-FFS farmers with Php55, 231.12. A difference of Php10,234.84, which was highly significant. FFS farmers have higher total production costs of Php28,274.83 compared to Non-FFS farmers with Php25, 147.26, a difference of Php3,127.57. FFS and non-FFS farmers have a difference in net income of Php7, 2017.27. FFS farmers have a higher net income of Php37, 191.13 compared to non-FFS farmers with Php30, 083.86. The high net income of FFS farmers translated to a net profit-cost ratio of 1.32 . This means 
that a farmer received a return of Php1.32 per peso invested in rice production. The results indicated that farmers under the FFS program tend to have higher net income/profit compared to non-FFS farmers (Mariano et al., 2012).

Table 7. Wet cropping season rice production of FFS and non-FFS farmers

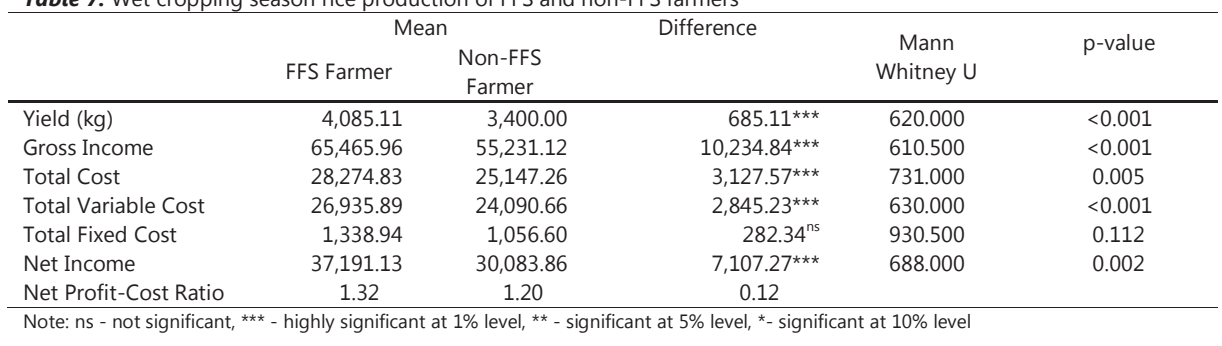

\section{Farmers' Rice Profitability for Dry Cropping Season Rice Production}

During the dry cropping season of 2019, FFS farmers produced a higher yield of $3,600 \mathrm{~kg}$ or $3.6 \mathrm{t} /$ ha compared to Non-FFS farmers with $3,152.13 \mathrm{~kg}$ or $3.15 \mathrm{t} / \mathrm{ha}$ (Table 8). A difference of $447.87 \mathrm{~kg}$ was highly significant at a $1 \%$ level $(U=732.00, p$-value $<0.005)$. FFS farmers have a higher gross income of Php56,009.57 compared to non-FFS farmers with Php48,755.32. A difference of Php7,254.26, which was highly significant. FFS farmers have higher total production costs of Php27,302.26 compared to Non-FFS farmers with Php24,755.32, a difference of Php2,559.21. FFS farmers have a higher net income of Php28,707.32 compared to Non-FFS farmers with Php24,012.28. FFS and non-FFS farmers have a difference in net income of P4,695.04. The results indicated that farmers under the FFS program tend to have higher net income/profit compared to non-FFS farmers (Mataia et al., 2015).

Table 8. Dry cropping season rice production of FFS farmers and Non-FFS farmers

\begin{tabular}{|c|c|c|c|c|c|}
\hline & \multicolumn{2}{|c|}{ Mean } & \multirow[t]{2}{*}{ Difference } & \multirow[b]{2}{*}{ Mann Whitney U } & \multirow{2}{*}{$p$-value } \\
\hline & FFS Farmer & $\begin{array}{c}\text { Non-FFS } \\
\text { Farmer }\end{array}$ & & & \\
\hline Yield $(\mathrm{kg})$ & $3,600.00$ & $3,152.13$ & $447.87^{* * *}$ & 732.000 & 0.005 \\
\hline Gross Income & $56,009.57$ & $48,755.32$ & $7,254 \cdot 26^{* \star *}$ & 717.500 & 0.003 \\
\hline Total Cost & $27,302.26$ & $24,743.04$ & $2,559.21^{* * *}$ & 701.000 & 0.002 \\
\hline Total Variable Cost & $25,947.36$ & $23,686.45$ & $2,260.91^{\star * *}$ & 721.500 & 0.004 \\
\hline Total Fixed Cost & $1,354.89$ & $1,056.60$ & $298.30 *$ & 911.000 & 0.074 \\
\hline Net Income & $28,707.32$ & $24,012.28$ & $4,695.04^{* *}$ & 823.500 & 0.034 \\
\hline Net Profit- Cost Ration & 1.05 & 0.97 & 0.08 & & \\
\hline
\end{tabular}

\section{Annual Rice Production}

For the annual rice production, FFS farmers produced a higher yield of $3,842.55 \mathrm{~kg}$ or $3.8 \mathrm{t} / \mathrm{ha}$ compared to non-FFS farmers with $3,279 \mathrm{~kg}$ or $3.28 \mathrm{t} / \mathrm{ha}$ (Table 9). FFS farmers were much higher with $566.49 \mathrm{~kg}$, which was highly significant at a $1 \%$ level $(U=658.00, p$-value $<0.001)$. The low rice yields among non-FFS farmers were attributed to the poor management of agricultural inputs and drought. FFS farmers have a higher gross income of Php60,680.32 than non-FFS farmers with Php51,956.72, a difference of Php8,723.60. FFS farmers acquired higher total production costs of Php27,797.59 compared to Non-FFS farmers with Php24,928.02 because of the sufficient amount of fertilizer used and proper weeding and insect pest and diseases management. FFS farmers have a higher net income of Php32,882.73 compared to Non-FFS farmers with Php27,028.69. The high net income of FFS farmers translated to a net profit-cost ratio of 1.18. This means that an FFS farmer received a return of Php1.18 per peso invested in rice production. This translates the effectiveness of the FFS program in improving the productivity and profitability of rice farmers (Gbawoquiya, 2017). 
Table 9. Annual rice production of FFS farmers and non-FFS farmers

\begin{tabular}{|c|c|c|c|c|c|}
\hline & \multicolumn{3}{|c|}{ Mean Difference } & \multirow[b]{2}{*}{ Mann Whitney U } & \multirow{2}{*}{$\mathrm{p}$-value } \\
\hline & FFS Farmer & $\begin{array}{l}\text { Non-FFS } \\
\text { Farmer }\end{array}$ & & & \\
\hline Yield (kg) & $3,842.55$ & $3,276.06$ & $566.49 * * *$ & 658.000 & 0.001 \\
\hline Gross Income & $60,680.32$ & $51,956.72$ & $8,723.60^{\text {*** }}$ & 652.000 & 0.001 \\
\hline Total Cost & $27,797.59$ & $24,928.02$ & $2,869.56^{\star * *}$ & 666.000 & 0.001 \\
\hline Total Variable Cost & $26,442.69$ & $23,871.43$ & $2,571.27^{* \star *}$ & 679.000 & 0.001 \\
\hline Total Fixed Cost & $1,354.89$ & $1,056.60$ & $298.30^{*}$ & 911.000 & 0.074 \\
\hline Net Income & $32,882.73$ & $27,028.69$ & $5,854.04^{\star * *}$ & 739.000 & 0.006 \\
\hline
\end{tabular}

\section{Regression Analysis}

The result reveals that being an FFS farmer means a significantly higher (at $1 \%$ level) net annual income of Php 6,761.00 per hectare than the non-FFS farmer (Table 10). On average, farmers that are college-level have a higher rice income of Php 2,898 than elementary level.

Table 10. Relationship between socio-demographic characteristics and FFS to knowledge, attitude, practice, and profitability

\begin{tabular}{|c|c|c|c|c|}
\hline \multirow{2}{*}{$\begin{array}{l}\text { Independent } \\
\text { Variables }\end{array}$} & \multicolumn{4}{|c|}{ Dependent Variables } \\
\hline & Knowledge & Attitude & Practice & Profit \\
\hline \multirow[t]{2}{*}{ FFS } & $0.428^{\star \star \star}$ & $0.440^{\star \star \star *}$ & $0.554^{* * *}$ & $6,761^{\star *}$ \\
\hline & $(0.112)$ & $(0.106)$ & $(0.116)$ & $(2,820)$ \\
\hline \multirow[t]{2}{*}{ Male } & -0.0773 & -0.000202 & -0.0751 & -338.3 \\
\hline & $(0.119)$ & $(0.113)$ & $(0.124)$ & $(2,997)$ \\
\hline \multirow[t]{2}{*}{ Age } & -0.00778 & -0.00455 & 0.00215 & 84.57 \\
\hline & $(0.00630)$ & $(0.00599)$ & $(0.00658)$ & $(159.3)$ \\
\hline \multicolumn{5}{|l|}{ Education } \\
\hline \multirow[t]{3}{*}{ High School } & -0.0885 & -0.0294 & -0.128 & $-3,731$ \\
\hline & $(0.0996)$ & $(0.0948)$ & $(0.104)$ & $(2,518)$ \\
\hline & & & - & \\
\hline \multirow[t]{2}{*}{ College } & 0.0873 & 0.0591 & 0.000528 & $2,898^{*}$ \\
\hline & $(0.180)$ & $(0.171)$ & $(0.188)$ & $(2,540)$ \\
\hline \multirow[t]{2}{*}{ Vocational } & -0.0329 & -0.0235 & 0.252 & 4,885 \\
\hline & $(0.414)$ & $(0.394)$ & $(0.432)$ & $(5,464)$ \\
\hline \multicolumn{5}{|l|}{ Civil Status } \\
\hline \multirow[t]{2}{*}{ Married } & $0.285^{\star *}$ & 0.0264 & -0.0364 & 782.3 \\
\hline & $(0.114)$ & $(0.109)$ & $(0.120)$ & $(2,894)$ \\
\hline \multirow[t]{2}{*}{ Widowed } & -0.0542 & 0.337 & 0.421 & $-3,163$ \\
\hline & $(0.328)$ & $(0.312)$ & $(0.343)$ & $(8,293)$ \\
\hline \multirow[t]{2}{*}{ Live-in/Others } & $0.984^{\star *}$ & 0.538 & 0.545 & 15,318 \\
\hline & $(0.476)$ & $(0.453)$ & $(0.498)$ & $(12,045)$ \\
\hline \multicolumn{5}{|l|}{ Tenurial } \\
\hline \multirow[t]{2}{*}{ Tenant } & -0.0694 & -0.0598 & 0.0281 & $-2,295$ \\
\hline & $(0.100)$ & $(0.0954)$ & $(0.105)$ & $(2,536)$ \\
\hline \multirow[t]{2}{*}{ Rental } & 0.293 & 0.0784 & 0.352 & 1,222 \\
\hline & $(0.217)$ & $(0.206)$ & $(0.227)$ & $(5,486)$ \\
\hline \multirow[t]{2}{*}{ Years in farming } & $0.00899^{*}$ & 0.000174 & -0.00424 & $110.0^{*}$ \\
\hline & $(0.00535)$ & $(0.00509)$ & $(0.00558)$ & $(35.2)$ \\
\hline \multirow[t]{2}{*}{ Constant } & $0.508^{*}$ & $0.775^{\star \star \star}$ & 0.328 & $26,767^{* \star *}$ \\
\hline & $(0.288)$ & $(0.274)$ & $(0.300)$ & $(7,268)$ \\
\hline Observations & 88 & 88 & 88 & 88 \\
\hline R-squared & 0.387 & 0.260 & 0.412 & 0.184 \\
\hline
\end{tabular}


Moreover, married farmers are more knowledgeable in terms of FFS practices as compared to single farmers. Increasing years of farming increases the probability of having high knowledge in FFS practices and technology management in farming. These findings were supported by the studies of Mariano et al. (2012) and Davis et al. (2012), wherein FFS effectively reinforced rice productivity of farmers due to the acquired knowledge in regards to efficient utilization of production technologies and management practices of crops. FFS farmers likewise increased their net income, which conformed with the findings of Castaňeda (2009), Godtland et al. (2004), and Gbawoquiya (2017), wherein FFS was the most successful program related to farmers' management and technology adoption in increasing productivity, efficiency, and profitability.

Additionally, Roy et al. (2014) and Arellano and Reyes (2019) stated that FFS soil and crop management technologies could maintain sustainable agriculture in regards to the profitability of the farmers.

\subsection{Conclusion}

The study showed positive effects of the Farmer Field School (FFS) on rice farmers' knowledge, attitude, and practices and the farm profitability of the rice enterprise. The effects of the FFS on the farmers' rice enterprise were reflected by the increase in knowledge, improvement in attitude towards the farming technologies, and improved farm practices on the Palaycheck System. In addition, it is concluded that FFS farmers' knowledge, attitude, and practice were positively correlated with profit/ income. Farmers with high knowledge, a positive attitude, and always practicing the Palaycheck system gained more profit. Therefore, farmers should acquire more knowledge, have a better attitude, and practice more on new production technologies to increase productivity and profit.

On the other hand, non-FFS farmers consistently performed lower in all parameters, and can be concluded that Palaycheck System can significantly improve farmers' KAP and profitability if adopted. Hence, there is a need to enhance more the technical knowledge of farmers on the appropriate and efficient use of inputs, particularly on the recommended seeding rate, fertilizer rate, and time of application. The study recommended that for future research, satisfaction and economic well-being of farmers might be embedded in the analysis as a potential limitation of the current paper.

\section{REFERENCES}

Arellano, C. A., \& Reyes, J. A. D. (2019). Effects of farmer-entrepreneurial competencies on the level of production and technical efficiency of rice farms in Laguna, Philippines. Journal of the International Society for Southeast Asian Agricultural Sciences, 25(2), 45-57.

Belanio, J. L. R., Hernando, C. M. D., Dumpir, D. Z. J., \& Sartorio, M. R. (2018). A qualitative assessment of agri-entrepreneurship development services for agrarian reform communities in Buruanga, Aklan, Philippines. Journal of Economics, Management \& Agricultural Development, 4(2390-2021-403), 61-76. https://doi.org/10.22004/ag.econ.309418

Casinillo, L. F. (2020). Econometric modelling on satisfaction in rice farming under Philippine rice tariffication law. Journal of Research and Multidisciplinary, 3(2), 326-336. https://doi.org/10.5281/jrm.v3i2.38

Castañeda, A. C. (2009). Changes in the technical efficiency of Philippine rice farmers. Philippine Journal of Crop Science (Philippines).

Castañeda, A. C., Bordey, F. H., \& Arocena, A. (2009). Three-season performance assessment of the PalayCheck System, 2005-2007. Philippine Journal of Crop Science, 34, 67.

Corales, A. M., Dizon, J. T., \& Cardenas, V. R. (2014). Assessing Palaycheck ${ }^{\circledR}$ Institutionalization in selected municipalities in Luzon, Philippines. Philippine Journal of Science, 143(2), 167-176.

Chi, T. T. N., Hossain, M., \& Palis, F. (2004). Impact of integrated pest management-farmer field school (IPM-FFS) on farmers' insect pest management belief, attitude, and practices (KAP) in Vietnam. Omonrice, 12, 109-119.

Cruz, R. T., Llanto, G. P., Castro, A. P., Barroga, K. E. T., Bordey, F., Redoña, E. D., \& Sebastian, L. S. (2005). PalayCheck: The Philippines rice integrated crop management system. IRC Newsl, 20, 83-91.

Centino, Z. M. H., \& Vista, A. B. (2018). Determinants of corn farmers to adapt to climate change impacts in Sagbayan, Bohol, Philippines. Annals of Tropical Research, 40(2), 77-89. https://doi.org/10.32945/ atr4027.2018

Davis, K., Nkonya, E., Kato, E., Mekonnen, D. A., Odendo, M., Miiro, R., \& Nkuba, J. (2012). Impact of farmer field schools on agricultural productivity and poverty in East Africa. World Development, 40(2), 402-413. https:// doi.org/10.1016/j.worlddev.2011.05.019

Gbawoquiya, P. D. (2017). Effectiveness of farmer field schools in improving agricultural productivity in Tanzania: $A$ case study of smallholder rice farmers in Mvomero district, Morogoro region (Doctoral dissertation, Sokoine University of Agriculture). 
Godtland, E. M., Sadoulet, E., Janvry, A. D., Murgai, R., \& Ortiz, O. (2004). The impact of farmer field schools on knowledge and productivity: A study of potato farmers in the Peruvian Andes. Economic development and cultural change, 53(1), 63-92. http://www.suaire.sua.ac.tz/handle/123456789/2222

Manalo IV, J. A., Pasiona, S. P., \& Bautista, A. M. F. (2021). Understanding the complexities in the adoption of the Rice Crop Manager tool in the Philippines. International Journal of Agricultural Sustainability, 1-12. https:// doi.org/10.1080/14735903.2021.1934363

Mariano, M. J., Villano, R., \& Fleming, E. (2012). Factors influencing farmers' adoption of modern rice technologies and good management practices in the Philippines. Agricultural Systems, 110, 41-53. https://doi. org/10.1016/j.agsy.2012.03.010

Mataia, A. B., Olivares, R. O., Manalili, R. G., Malasa, R. B., \& Litonjua, A. C. (2015). Impact of farmer field schoolpalaycheck" in the irrigated rice areas in the Philippines. Philippine Journal of Crop Science (PJCS), 40(3), 49-61.

Philippine Rice Research Institute (PhilRice). (2007). Palaycheck system for irrigated lowland rice. Philippine Rice Research Institute and Food and Agriculture Organization.

Philippine Statistics Authority (PSA). (2018). Major crops statistics of the Philippines 2017-2018. https://psa.gov.ph/ content/crops-statistics-philippines-national-and-regiona

Portera, E. F., \& Hila, A. C. (2020). Liberating farmers from tenancy bondage: The land and agrarian reform programs of Ramon Magsaysay (1954-1957). Philippine Social Science Journal, 3(1), 142-154. https://doi. org/10.52006/main.v3i1.118

Price, L. L. (2001). Demystifying farmers' entomological and pest management knowledge: A methodology for assessing the impacts on knowledge from IPM-FFS and NES interventions. Agriculture and human values, 18(2), 153-176. https://doi.org/10.1023/A:1011163307355

Roy, D., Farouque, G., \& Rahman, Z. (2014). Practice of soil and crop management technologies by the FFS farmers for maintaining sustainable agriculture. European Academic Research, 2(6), 8282-8297.

Samoy-Pascual, K., Bautista, E. G., Valdez, H. V., \& Gagelonia, E. C. (2019). Effect of wetland preparation period on weed density and grain yield of transplanted lowland rice. Philippine Journal of Crop Science (PJCS), 44(1), 44-50.

Schwartz, N. E. (1976). Nutrition knowledge, attitudes, and practices of Canadian public health nurses. Journal of Nutrition Education, 8(1), 28-31. https://doi.org/10.1016/S0022-3182(76)80113-6

Valenzona, R. M. P., Amestoso, N. T., \& Casinillo, L. F. (2020). Assessing the success of farmers' associations: The case of Baybay City, Leyte, Philippines. Journal of Agriculture and Technology Management (JATM), 23(1), 14-25.

Yagos, R. M., \& Demayo, C. G. (2015). Farmer's perceptions on rice production management practices in Bayog, Zamboanga Del Sur, Mindanao, Philippines. Journal of Scientific Research and Development, 2(14), 96-101. https://www.researchgate.net/publication/305956405

\section{Correspondence:}

FROLINE S. RED

froline93@gmail.com

https://orcid.org/0000-0002-3211-389X

NILDA T. AMESTOSO

nilda.amestoso@vsu.edu.ph

https://orcid.org/0000-0002-7606-8621

LEOMARICH F. CASINILLO*

leomarichcasinillo02011990@gmail.com

https://orcid.org/0000-0003-3966-8836

*Corresponding Author 